\title{
Governance of Ecosystem Services Across Scales in Bangladesh
}

\author{
Andrew Allan and Michelle Lim
}

\subsection{Introduction}

Ecosystem services (MEA 2005) are governed and affected by a diverse variety of different legal and governance frameworks (Paavola et al. 2009), although analysis of these legal frameworks has rarely been carried out (Salzman et al. 2001). Ideally, these frameworks are integrated and coordinated with a view to achieving common objectives, but in reality they are often developed and implemented within sectoral boundaries without reference to each other. For example, the provisioning ecosystem service of freshwater is potentially affected by management and policy decisions related to water abstraction, pollution control and agricultural land use and flood risk alleviation, among others. Laws and institutions often fail to address cross-cutting issues that are shared across sectors and approaches to these issues are therefore frequently fragmented and incomplete.

A. Allan $(\bowtie)$

School of Law, University of Dundee, Dundee, UK

M. Lim

Adelaide Law School, University of Adelaide, Adelaide, SA, Australia

(C) The Author(s) 2018

R. J. Nicholls et al. (eds.), Ecosystem Services for Well-Being in Deltas, https://doi.org/10.1007/978-3-319-71093-8_6 
Lack of policy integration is widely observed, and although it may be explained as a product of the increasing complexity involved in effectively dealing with difficult issues, such as the demands that are imposed by choosing to implement integrated water resources management, it is also in part a function of weaknesses in government planning structures.

An important aspect of the research undertaken in the study area was to understand the ways in which ecosystem services are related to poverty alleviation. One way to begin interrogating the relationship between these two domains is to question whether or not the benefits that might be derived from ecosystem services are actually accessible by those who can most profit from them. The staged approach to ecosystem services proposed by Fisher et al. (2009) is relevant here, the theory positing that intermediate ecosystem services require an additional catalyst in the form of one or other type of capital in order to render their potential benefits actually realisable. Governance frameworks are relevant not only to the quality and extent of the ecosystem services themselves but also to the ability of people to enjoy their benefits (see, e.g. Butler and OluochKosura 2006). Consequently, the governance research examines the legal, institutional and policy frameworks that both affect the quality of the ecosystem services and those influencing an individual or community's ability to enjoy the derived benefits.

The research therefore focuses on legislative coherence especially across sectors, transposition of international obligations, adherence to international best practice and the extent to which policy objectives are supported by the legal foundation. In the particular context of the Ganges-Brahmaputra-Meghna (GBM) delta, this entails consideration of formal documented policies, regulations and statutes (and case law where appropriate), especially those documents that are legally enforceable, affect multiple sectors, and are at an administrative scale where decisions could be made that would affect ecosystem services and livelihoods. The fact that in some cases decision making is either devolved or decentralised within national boundaries and that the GBM basin is shared by five riparian states (China, India, Bangladesh, Nepal and Bhutan) meant that multiple scales have to be examined. Analysis of the factors that influence the implementation and achievement of policy objectives, and the extent to which legal and institutional frameworks are capable of supporting 
policy is also necessary (Hill Clarvis et al. 2014). This analysis of barriers was extended to cover informal governance systems as far as possible, in order to understand the degree of coherence between local customary systems and more formal frameworks.

Finally, the governance work investigates ways in which governance quality might be incorporated into the modelling work that integrated the major biophysical elements of ecosystem services with the health and livelihood findings of the household survey. Even an elementary quantification of the influence of governance quality may usefully inform decision-making choices as regards appropriate interventions for alleviating poverty.

\subsection{Policy and Legislation}

The governance analysis focuses on around 80 pieces of legislation and policy relevant to the sources of ecosystem services (including water and land use management, fisheries, and environmental protection) and to the protection and improvement of livelihoods (e.g. human rights and rural development). Identification of the areas of relevant law is linked primarily to the conceptualisation of the relationship between ecosystem services and poverty alleviation and the factors mediating between these. As seen in Chap. 4, these were identified as access and entitlements, mobility and urban areas, community and informal institutions and health. This wide range of factors is both affected and governed by a vast spectrum of legal and policy frameworks, so limiting the scope to the key elements only is imperative for the preliminary analysis.

Areas of governance of potential relevance are therefore identified. Access and entitlement to resources are governed primarily by the framework for apportioning rights of use and access to water resources, along with property rights and land tenure. These are also influenced by rights to use and access forests for timber and non-timber forest products, with any frameworks allocating rights to fish. In many areas, local customary legal and institutional systems have not yet been supplanted by more formal sources, especially in relation to resource entitlements (e.g. land, water, fisheries-Freestone et al. 1996), so must also be considered. 
The quality and extent of resource use entitlements are critically dependent upon the extent to which resources can be protected; understanding the governance context for pollution control and environmental management is consequently required. In relation to broader questions of mobility and health, the existence of appropriate human rights regardless of location is a crucial consideration, in both substantive and procedural form, with access to information rights underpinning the latter, forming part of the foundation for the wider cross-sectoral governance context. Land use planning capacity is also a concern with respect both to access and entitlements, but also in relation to urban areas and disaster risk management. The prevention, management and alleviation of disasters are increasingly addressed through holistic governance frameworks, the quality of which can drastically affect population vulnerability and resilience. Finally, access to justice and remediation (including through local courts) is imperative for the enforcement of rights and obligations under each of the foregoing categories.

\subsubsection{The International Context}

Not all relevant legislation or policy will be set out in detail here-nor does space allow a detailed analysis of the international legal framework. There are certain key areas of law that are particularly important for both ecosystem services and poverty alleviation, however. The first are those legal frameworks concerning freshwater, which are central to the ecosystem services within the study area (Rieu-Clarke and Spray 2013), addressing both quantity, flow and quality considerations. At the international scale, the GBM system is characterised by a general absence of a pan-watershed agreement (despite some bilateral arrangements further upstream), and none of the basin states have ratified the UN Watercourses Convention (UN 1997) or the UNECE Water Convention (UNECE 1992) although the latter has been open to states outside the UNECE area since 1 March 2016. A draft agreement on the use of the Teesta River has also yet to be signed, despite having been in existence for a number of years, and there is no formal agreement on shared groundwater. This leaves only the Farakka Treaty (1996), though this is 
limited in its application as it applies only to the dry season, contains no provisions on water quality, applies to only two riparian states and affects one of the basin rivers alone.

In addition, and to some extent, bridging the gap between ecosystem services and livelihoods are legal frameworks relating to human rights. Bangladesh has ratified both of the international human rights covenants, respectively, on Economic, Social and Cultural Rights (ICESCR 1966) and on Civil and Political Rights (ICCPR 1966), some of which have been transposed through the country's 1972 Constitution. The situation as regards human rights for migrants, especially those internally displaced for whatever reason, is less secure however (Allan et al. 2015).

\subsubsection{National Governance and Implementation}

At the national level, while legislation and policy exist, the general level of inter-sectoral coordination and legislative coherence, with notable exceptions, is rather discouraging. In addition, there are a number of barriers to the effective implementation and the age of legislation in many cases worrying. Examples include the Environment Policy of 1992 (its environmental impact assessment elements remain guidelines only) and the failure to translate the cross-sectoral Coastal Zone Policy of 2005 into practice. There are also a number of examples where primary legislation is in place, but is hobbled by the absence of implementing guidelines, subordinate legislation or rules required for it to have any impact (see, e.g. the Groundwater Management Ordinance ${ }^{1}$ ).

While the age of legislation is not in itself always problematic, there are areas where policy priorities have moved significantly globally over the past 20 or 30 years, and the pace of change is in fact increasing. Environmental protection and human rights are two such areas. In neither case is there much evidence of significant legislative shifts in Bangladesh over the past 20 years, and, in the context of forest management in particular, much of the land use management regime and compulsory purchase frameworks (where private land is expropriated for public purposes) continue to be heavily influenced by approaches from the British colonial period. Water resource management is something of 
an exception here, with the recent Water Act of 2013, although the detailed rules needed for implementation are yet to reach the statute book.

An allied issue relates to reporting and monitoring. The Planning Commission of Bangladesh contains a division that is dedicated to the implementation, monitoring and evaluation of public sector development projects, indicating the value that the government puts on ensuring that projects do what they are intended to do, at least initially. However, some of the indicators used by this division are problematic. For example, those relating to environmental sustainability correspond only loosely with what might be regarded as best practice (see, e.g. Bell and Morse 2008): forest coverage, length of waterways that are navigable all year round, number of cyclone shelters, what are described as the number of rural communities with disaster resilient habitats and community assets, and reductions in case backlogs in courts.

Clear criteria are needed to ensure accountability and transparency, but the level of detail necessary for this is not so apparent in some Bangladeshi legislation. For example, with respect to groundwater extraction, the criteria guiding decisions on permits for sinking tube-wells are very vague (Groundwater Management Ordinance 1985, s.5(4)), leaving decision makers almost unfettered discretion. This is compounded by serious restrictions on the ability of disappointed applicants to appeal against these decisions, including with respect to time restrictions. The balance between the length of time available for challenging decisions and the consequences of those decisions may be inappropriate. The Acquisition of Waste Land Act of 1950 provides an example. The authorities have the right under the Act to compulsorily acquire what is defined as 'waste land' for certain public purposes. Objections to such acquisition must be raised within 15 days of notification being made, at a limited number of places and only then by those who may have a right of compensation for the land being taken, taking no account of literacy or access to the appropriate information. Land tenure in Bangladesh is vulnerable to the rapid erosion processes on the GBM, and although legal provision for khas land appears to favour the poor, the reality of the application of the State Acquisition and Tenure Act 1950 (as amended) is that the poor are at the mercy of richer farmers (FAO 2010). Land tenure especially is further 
complicated by the influence of local customary frameworks, through the operation of the $s a m a j^{2}$ and adjudication of disputes (including those relating to land) through shalish ${ }^{2}$ tribunals (Lewis and Hossain 2008).

This latter point is also symptomatic of a more general trend towards asymmetry between the rights, powers and obligations of the government (and its officials) and the public. State authorities are given a significant degree of discretion in their decision making, and this is especially noticeable again when the consequences of a decision are weighed against the degree to which the decision is open to challenge. The Embankment and Drainage Act (1952) endows the engineer with extensive powers to enter into and to acquire land that is relevant to the construction of public embankments. Similarly, the determination of land as being 'waste land' for the purposes of the Acquisition of Waste Land Act, and the very broad definition of 'public purpose', and the lack of clarity in relevant criteria, leave a great deal of latitude to decision makers. Where, as in the case in the latter Act, access to the civil courts as a means of obtaining redress is expressly forbidden, the balance of power is very definitely on the side of the authorities. This compounds the general lack of participation and the marginalisation of the poor that takes place despite the increasing number of references to participatory approaches that appear in policy documents and legislation.

The lack of coordination and cooperation within and between ministries is a recurring theme within the literature and in interviews conducted as part of the project stakeholder engagement, but is also evident in the separation of different policy frameworks. This is compounded by a fragmented legal regime and inconsistencies within laws and regulations (Afroz and Alam 2013). Different aspects relating to the management of the Sundarbans, for example, are governed by separate legal regimes. The Forest Department (part of the Ministry of Environment and Forests-MoEF) is responsible for implementing the Forest Act 1927, and another wing of the same Ministry, the Department of Environment, is responsible for implementing the Environment Conservation Act 1995. The Department of Fisheries (part of the Ministry of Fisheries and Livestock) is responsible for monitoring fish stocks, but the Forest Department (MoEF) issues permits for fish collection inside the mangrove forests. These separate regimes create challenges for management and dif- 
ficulties for the control of fish stocks (Iftekhar 2010). They also suggest that the quality of governance of ecosystem services and the corresponding ability of people to enjoy the benefits the service provides may vary across social-ecological systems (see Chap. 22).

Frustratingly, however, it is also clear that cross-sectoral coordination is possible and practicable in Bangladesh, with the disaster management framework providing an excellent example of this. As shown in Fig. 6.1, policy and legislation were developed in close chronological proximity, appropriate institutional arrangements put in place rapidly, and the system now appears to work well.

The lack of enforcement financial and technical capacity also has a severe impact on implementation and management in Bangladesh. The effectiveness of legislation is compromised by the lack of enforcement (Afroz and Alam 2013), and this creates a large gap between the de jure commitment and the de facto reality.

\subsection{Relationship Between Policy and Legislation}

As previously noted, the success of the disaster management architecture in Bangladesh may in part be a result of the way in which policy was developed almost in tandem with the required legal framework. What then is the relationship between policy and legal frameworks in this context? While recognising that policy aims may not be directly dependent on the capacity of legal frameworks to support them (e.g. infrastructure development, changes in investment priorities or capacity development), analysis suggests that while there may be policy development in areas that are important for ecosystem services and livelihoods, this may not be followed up with linked improvements in legal frameworks.

This is not to say that there is no connection between the two. The Disaster Management Plan was very rapidly translated into legal effect, for example, through the Standing Orders on Disaster. This is in line with the idea that disasters may precipitate what Pelling and Dill call 'a tipping point in the social contract' (Pelling and Dill 2010), though in this case the development of both the disaster management policy and legislation 
Governance of Ecosystem Services Across Scales in Bangladesh

\begin{tabular}{|c|c|c|}
\hline Policy & Year & Legislation \\
\hline National Social Protection Strategy (3rd draft) & 2014 & \\
\hline & 2013 & Water act \\
\hline & 2012 & \\
\hline & 2011 & \\
\hline $\begin{array}{r}\text { Sixth Five Year Plan } \\
\text { Plan for Disaster management } \\
\text { National Industrial Polict } \\
\text { Perspective Plan } \\
\text { Child labour Elimination Policy }\end{array}$ & 2010 & Standing Orders on Disasters \\
\hline $\begin{array}{r}\text { National Adaptation Plan of Action } \\
\text { National Tiger Action Plan }\end{array}$ & 2009 & Right to Information Act \\
\hline & 2008 & \\
\hline & 2007 & \\
\hline $\begin{array}{r}\text { Coastal Development Strategy } \\
\text { National Fisheries Strategy } \\
\text { National Food Policy }\end{array}$ & 2006 & \\
\hline \multirow[t]{3}{*}{$\begin{array}{l}\text { Fifth Five Year Plan } \\
\text { Coastal Zone Policy }\end{array}$} & 2005 & \\
\hline & 2004 & \\
\hline & 2003 & \\
\hline Population Policy & 2002 & \\
\hline \multirow[t]{2}{*}{ Rural Development Policy } & 2001 & \\
\hline & 2000 & $\begin{array}{l}\text { Environment Court Act } \\
\text { Water Development Board Act }\end{array}$ \\
\hline National Water Policy & 1999 & \\
\hline \multirow[t]{4}{*}{ National Fisheries Policy } & 1998 & \\
\hline & 1997 & Environment Conservation Rules \\
\hline & 1996 & Ganges Water Sharing Treaty \\
\hline & 1995 & $\begin{array}{l}\text { Environment Conservation Act } \\
\text { Protection and Conservation of Fisheries (Amendment) } \\
\text { Act }\end{array}$ \\
\hline National Forest Policy & 1994 & \\
\hline
\end{tabular}

Fig. 6.1 Chronology comparing the development of policy and legislation 
can be seen partly as a response to Cyclone Aila in 2009 and also as part of an international continuum during the first ten years of this century where many countries adopted similar approaches, driven in part by the Hyogo Framework (Allan 2017) and the earlier Yokohama Strategy (UNISDR 1996).

The factors involved in other legislation and policy development are ordinarily rather different (South Africa is a key exception here, because of its unique circumstances at the end of the apartheid era), and it is therefore more difficult to interpret the relationship between the two elements of governance. A systematic review of policy development and correlative legal frameworks has not been done in relation to ecosystem services, and making firm inferences from such a study would be problematic as there are a multitude of factors that might have influence. Existing legislation may be adequate to support policy innovations or require merely a change in interpretation that can be manifested through operational guidelines (which would be invisible to such a study). Policy on the other hand may not require legislative intervention in order to achieve its objectives. There is also a question of breadth or scope. If principles of human behaviour can be established that are generally adhered to, for example, in national Constitutions (e.g. with respect to human rights in the case of Bangladesh and the adherence to international standards in law at least), it may be that no further change is needed. This is not the case with respect to the management of resources, for instance, where changing management practices are driven in part by increased understanding through science, the application of technology, involvement of broader swathes of stakeholders and potentially also changing resource availability (as a result, for instance, of demographic changes or the impacts of climate change). One consequence of this is that it becomes increasingly difficult for legal practice to keep up with societal change. Furthermore, the development of legislation is in some ways intrinsically more contentious than the development of policy simply because of the power structures inherent in legislatures. Policy puts objectives in place that are generally non-enforceable, while law (at least in theory) puts obligations and rights in place that are supposed to be backed by official sanction. 
Figure 6.1 does not unpick these difficulties, and further research is needed to analyse how it compares with other countries. The key elements that stand out include the fact that there is no corresponding legislation to implement the National Fisheries and Forestry policies (1998 and 1994 respectively), especially given the age of the existing forest legislation. The 14-year gap between the development of the National Water Policy and the 2013 Water Act is also noteworthy, especially as the latter is so closely aligned with the former. Finally, there is an unfortunate absence of a legal framework to implement the inter-sectoral 2005 Coastal Zone Policy. It is unrealistic to expect policy objectives to be met when there are no enforceable means of achieving them.

A number of other factors may influence the extent to which policy objectives may be implemented. These may include (i) adequate financial provision within government to support implementation, (ii) institutional capacity and effective coordination between separate agencies or institutions towards a common cross-sectoral objective and (iii) appropriate expectations as regarding the time and budget within which the objective should be fulfilled.

\subsection{Linking with the Integrated Modelling}

As discussed in Chap. 10, governance issues were clearly identified by interviewees and workshop attendees as being of concern in the study area, and the multiple facets of the concept were elucidated in great detail. In order to begin the process of quantifying the impact of governance on ecosystem services and livelihoods, efforts were made to incorporate governance metrics and indicators into the integrated modelling process in order to try to capture the governance situation in future projections.

The principal objective was to better understand the potential impact of varying qualities of governance regimes on the effectiveness of policy implementation, management, or infrastructural interventions intended to alleviate poverty or enhance the benefits derived from ecosystem services. Of the list of governance issues identified as part of the scenario development process, only around 40 per cent were considered even potentially capable of being represented in the integrated modelling 
work. This was due in part to limitations on modelling capacity (the integrated model simply cannot model everything) and to the difficulties encountered in trying to reflect governance quality in model-able inputs.

Firstly, identifying appropriate governance datasets that could be directly applicable was difficult. There is no commonly accepted definition of 'governance' across the multitude of indicator systems available (see, e.g. Arndt and Oman 2006), and there is no close sectoral overlap of indicator systems with the areas of governance being studied in the project. In addition, the temporal aspects of governance indicators raise obstacles against their use: even the most regularly updated indicators (such as the World Governance Indicators (Kaufmann et al. 1999) and the Corruption Perceptions Index ${ }^{3}$ are revised only once every year, with the more comprehensive assessments (including the World Bank CPIA (Country Policy and Institutional Assessment) measure and the UNDAF CCA (Common Country Assessment) process) conducted only every five years or so. Combined with the general lack of a long-term dataset to aid calibration, demonstrating governance trends over time in Bangladesh and in relation to the relevant governance frameworks is extremely challenging.

Secondly, and more crucially, the establishment of a causal or even an associative relationship between a governance intervention of any sort and a change in an indicator of biophysical or human well-being in such a broad arena as ecosystem services and livelihoods is virtually impossible. There are so many variables that may affect the success or otherwise of policy implementation that drawing a clear link between cause and effect is challenging in the extreme. This was further highlighted in the process of attempting to establish some sort of spatial explicitness with respect to governance indicators (i.e. from national level down to the project case study areas in the south-west of the country). This proved impracticable, not least because existing governance datasets are analysed as regards national state contexts and cannot be magnified to give finer resolution.

Therefore, it became clear that while the existence of certain elements of governance was obviously desirable, direct quantification of exactly how beneficial they might be is extremely challenging. These latter elements included institutional coordination, stakeholder involvement in decision making and forward planning. All are manifestly useful, but quantifying their influence will always involve a degree of speculation. 


\subsection{Conclusions}

The legal and policy infrastructure relating to ecosystem services is immensely complex, crossing multiple sectors and demanding a degree of institutional and policy coordination that is challenging even in the most developed nations. In addition, the capacity of the poor to access and enjoy the benefits produced by those services may be compromised by restrictions imposed by weak enforcement of applicable legal entitlements, difficulty in accessing justice or by the divergent demands of local informal governance frameworks compared to formal state systems.

It appears that governance frameworks in Bangladesh for water resource and land management rely to some extent on rather outdated policy and legislation. Further research is needed on better understanding the relationship between policy development and its translation into legislation (if needed). It is clear however that where the two are closely linked in time, it is possible for the requisite degree of coordination, cross-sectoral coherence and enforceability to be achieved; the disaster risk management process demonstrates that workable solutions can be developed even in the poorest countries.

Understanding the exact relationship between governance frameworks for ecosystem services and poverty alleviation through the incorporation of quantitative indicators in mathematical models requires additional research in order to assess compatibility with existing indicator sets, and for the incorporation of spatial explicitness. This would be bolstered by greater insight into the relationship between governance more generally and the biophysical environment.

\section{Notes}

1. All Bangladesh Acts and Laws mentioned in the text are available at http:// bdlaws.minlaw.gov.bd/

2. The term 'shalish' refers to a small-scale local council, distinct from the formal village court, which is convened for the purposes of civil and criminal conflict resolution. 'Samaj' refers to the community that convenes the shalish. (For more information, see Bode and Howes 2002.)

3. See Transparency International www.transparency.org 


\section{References}

Afroz, T., and S. Alam. 2013. Sustainable shrimp farming in Bangladesh: A quest for an integrated coastal zone management. Ocean and Coastal Management 71: 275-283. https://doi.org/10.1016/j.ocecoaman.2012.10.006.

Allan, A. 2017. Legal aspects of flood management. In Routledge handbook of water law and policy, ed. A. Rieu-Clarke, A. Allan, and S. Hendry. London: Earthscan.

Allan, A., A. Rieu-Clarke, C. Addoquaye Tagoe, S. Dey, A.K. Ghosh, M.S. Mondal, W. Nelson, M. Salehin, and C.L. Samling. 2015. Governance analysis. Working paper. Deltas, Vulnerability and Climate Change: Migration and Adaptation (DECCMA) project. www.deccma.com.

Arndt, C., and C. Oman. 2006. Uses and abuses of governance indicators. Paris: Organisation for Economic Co-operation and Development (OECD). http://www.oecd.org/dev/usesandabusesofgovernanceindicators.htm. Accessed 11 Jan 2017.

Bell, S., and S. Morse. 2008. Sustainability indicators: Measuring the immeasurable? 2nd ed. London: Earthscan.

Bode, B., and M. Howes. 2002. The north west institutional analysis. In Go-interfish project report. Dhaka: CARE Bangladesh. http://www.carebangladesh.org/shouhardoII/publication/Publication_4595642.pdf. Accessed 03 July 2017.

Butler, C.D., and W. Oluoch-Kosura. 2006. Linking future ecosystem services and future human well-being. Ecology and Society 11 (1): 30.

FAO. 2010. On solid ground: Addressing land tenure issues following natural disasters. Rome: Food and Agriculture Organization of the United Nations (FAO).

Farakka Treaty. 1996. Treaty between the Government of the people's Republic of Bangladesh and the Government of the Republic of India on sharing of the Ganga/Ganges water at Farakka. 36 I.L.M 523 (1997).

Fisher, B., R.K. Turner, and P. Morling. 2009. Defining and classifying ecosystem services for decision making. Ecological Economics 68 (3): 643-653. https://doi.org/10.1016/j.ecolecon.2008.09.014.

Freestone, D., M. Farooque, and S.R. Jahan. 1996. Legal implications of global climate change for Bangladesh. In The implications of climate and sea-level change for Bangladesh, ed. R.A. Warrick and Q.K. Ahmad, 289-334. Dordrecht: Springer. 
Hill Clarvis, M., A. Allan, and D.M. Hannah. 2014. Water, resilience and the law: From general concepts and governance design principles to actionable mechanisms. Environmental Science \& Policy 43: 98-110. https://doi. org/10.1016/j.envsci.2013.10.005.

ICCPR. 1966. International covenant on civil and political rights. United Nations. 999 UNTS 171.

ICESCR. 1966. International covenant on economic social and cultural rights. United Nations. 993 UNTS 3.

Iftekhar, M.S. 2010. Protecting the Sundarbans: An appraisal of national and international environmental laws. Asia Pacific Journal of Environmental Law 13 (2): 249-226.

Kaufmann, D., A. Kraay, and P. Zoido-Lobaton. 1999. Aggregating governance indicators. Policy research working paper no. 2195. Washington, DC: World Bank. http://info.worldbank.org/governance/wgi/pdf/govind.pdf. Accessed 31 May 2017.

Lewis, D., and A. Hossain. 2008. Understanding the local power structure in rural Bangladesh. SIDA studies no. 22. Stockholm: SIDA. http://personal.lse.ac. uk/lewisd/images/Lewis\&H-SidaStudies-22.pdf. Accessed 31 May 2017.

MEA. 2005. Ecosystems and human well-being: Synthesis. In Millennium ecosystem assessment (MEA). Washington, DC: Island Press. http://www.millenniumassessment.org/documents/document.356.aspx.pdf. Accessed 01 Aug 2016.

Paavola, J., A. Gouldson, and T. Kluvánková-Oravská. 2009. Interplay of actors, scales, frameworks and regimes in the governance of biodiversity. Environmental Policy and Governance 19 (3): 148-158. https://doi. org/10.1002/eet.505.

Pelling, M., and K. Dill. 2010. Disaster politics: Tipping points for change in the adaptation of sociopolitical regimes. Progress in Human Geography 34 (1): 21-37. https://doi.org/10.1177/0309132509105004.

Rieu-Clarke, A., and C. Spray. 2013. Ecosystem services and international water law: Towards a more effective determination and implementation of equity? Potchefstroom Electronic Law Journal 16 (2): 12-65.

Salzman, J., B.H. Thompson Jr, and G.C. Daily. 2001. Protecting ecosystem services: Science, economics and law. Stanford Environmental Law Journal 20: 309-332.

UN. 1997. Convention on the law of non-navigational uses of international watercourses. United Nations. May 21 (in force 17 August 2014), reprinted in 36 I.L.M 700. 
UNECE. 1992. Convention on the protection and use of transboundary watercourses and international lakes. United Nations Economic Commission for Europe. March 17 (in force 6 October 1996) 1936 UNTS 269; 31 ILM 1312.

UNISDR. 1996. Yokohama strategy and plan of action for a safer world: Guidelines for natural disaster prevention, preparedness and mitigation. World conference on natural disaster reduction. Geneva: United Nations Office for Disaster Risk Reduction (UNISDR). http://www.unisdr.org/files/8241_doc6841contenido1.pdf. Accessed 01 June 2017.

Open Access This chapter is licensed under the terms of the Creative Commons Attribution 4.0 International License (http://creativecommons.org/licenses/ by/4.0/), which permits use, sharing, adaptation, distribution and reproduction in any medium or format, as long as you give appropriate credit to the original author(s) and the source, provide a link to the Creative Commons license and indicate if changes were made.

The images or other third party material in this chapter are included in the chapter's Creative Commons license, unless indicated otherwise in a credit line to the material. If material is not included in the chapter's Creative Commons license and your intended use is not permitted by statutory regulation or exceeds the permitted use, you will need to obtain permission directly from the copyright holder.

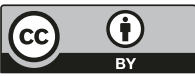

